\title{
One of the Great Pioneers of Anatomy: Gabriele Falloppio (1523-1562)
}

Çağatay ÖNCEL

Department of Neurology, Pamukkale University School of Medicine, Denizli, Turkey

\section{ABSTRACT}

Gabriele Falloppio (1523-1562) was one of the greatest anatomists of medical history. He discovered and named numerous parts of the human body. This review aims to report some information regarding his life and studies.

Keywords: Gabriele Falloppio, anatomy, Padua School

Gabriele Falloppio was born in 1523 in the city of Modena, northern Italy. His father belonged to a noble family. He first started studying classical sciences (e.g., philosophy, literature, and philology) and then moved on to priesthood because of the financial difficulties faced by his family after his father's early death. When their financial situation improved, he started studying medicine in Modena with the help of his uncle. He had an insatiable curiosity and read texts of Galen (130-201) and Berengario da Carpi (1460-1530), thoroughly learning anatomy, surgery, and pharmacology. He performed dissections on hanged criminals $(1,2)$. In 1540, he went to Ferrara, where at that time, one of the best medical schools in contemporary Europe was situated. After receiving an education as a student of Giambattista Canano and Antonio Brasavola, in 1548 at the age of 25, he was appointed the head of Pisa University's Anatomy and Surgery Department by the Duke of Florence, Cosimo de Medici. He was located in Padua for a while; it is uncertain if he studied there with Andreas Vesalius (1514-1564), who is regarded as the founder of anatomy. However, he was greatly influenced by the anatomy book of Vesalius, De Humani Corporis Fabrica $(3,4)$.

He performed vivisections during his 3 years in Pisa (Vivisection is a dissection type that has been performed since antiquity and that enables the observation of people's internal organs and their change; it was usually performed on convicted criminals at that time.). He studied pharmacological features of plants, utilizing Latin, Greek, and Islamic medicine. In 1551, the Senate of Venice endowed him with the honor of anatomy, surgery, and botany professorship in the famous Padua University (Figure 1). Thereafter, he started to fill Vesalius' chair. Falloppio's fame spread, and his patients included members of well-known families and the brother of the Pope. In 1556, he developed chronic fatigue, followed by a chronic lung disease. He died on October 9, 1562; his disease was probably tuberculosis. He was buried in the Saint Anthony Church of Padua (4-8).

Considering his contributions to medicine, he completed his book entitled "Observationes Anatomice" in 1561, which he started in 1557, and the book was published in Venice (Figure 2). He dedicated his book to Petrus Manna who was the physician of The Duke of Milano, Francesco Sforza. The book contained no drawings or figures, and it included numerous anatomical discoveries and writings, which corrected several mistakes present in the De Humani Corporis Fabrica of Vesalius and Galen's anatomy teachings. This prompted Vesalius to write a letter disparaging his works, but this did not achieve any results. The following anatomical formations bear his name:

- Tuba uterine (Fallopian tube). (This is described earlier by Herophilos, Galen, and Rufus of Ephesus, but Falloppio is the first to describe its function and mention it as the trumpets of the uterus. $)(5,8,9)$.

- Entry point of n. petrosus superficialis major into the petrous bone (fallopian hiatus). 


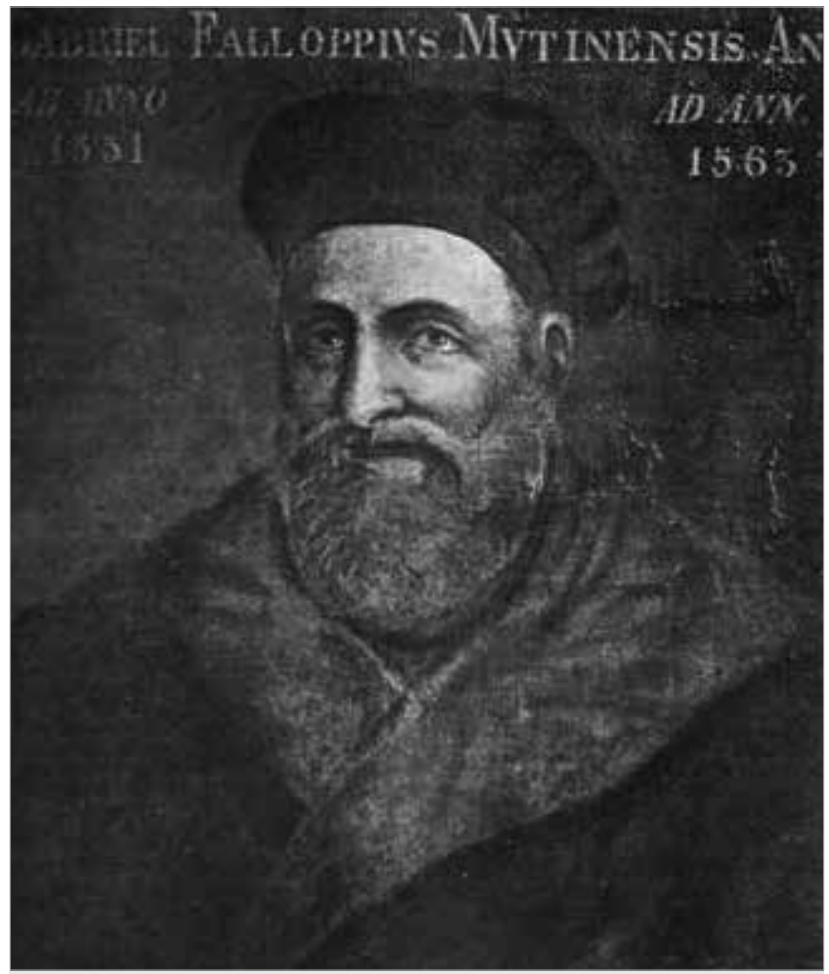

Resim 1. Gabriele Falloppio (1523-1562)

\section{GABRIELIS FALLOPPII} MEDICI MVTINENSIS

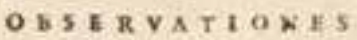

AD PE'TRVM MANNAM medicum Cremoneafem.

\section{Cum Privilegio Summi Pontificis, Regis Philippi, Senatusque Veneti.}

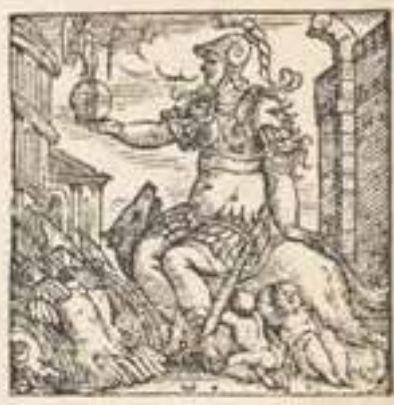

V E N E T I I S. Apud Marcum Antonium uos M D L X I.

Resim 2. Falloppio'nun meşhur kitabı Observationes Anatomicae
The small canal of the facial nerve along the petrous part of the temporal bone, the-facial canal (fallopian canal).

He described the palatum state and muscles in the palatum molle and pharyngeal muscle. The pyramidalis muscle bears his name (fallopian muscle).

Ileocecal valve (fallopian valve)

His contributions to neuroanatomy include the following. He was the first researcher to investigate the sphenoid and temporal bones in detail. The chorda tympani, lacrimal bone, and lacrimal canal were described in detail. He described the circulation of the carotid and vertebral arteries. He was the first to describe the structure currently known as the Willis Polygon in 1561, approximately a hundred years before Thomas Willis (1621-1675). He introduced the terms placenta, vagina, cricoid, and tympanum to terminology. He explained the ossification process of the occipital bone and sternum and described the tooth development process. He reached these last descriptions after working on numerous fetus, infant, child and adult cadavers. These contributions to developmental anatomy and embryology were extended by two of his students [Hieronymus Fabricius (1537-1619) and Volcher Coiter (1534-1576)] who continued and developed this method. Cranial nerves IV, V, VII, IX were described in detail $(1-5,10)$.

His works on the inner ear are among his most important works. He is the first to competently describe the round and oval windows, semicircular canals, cochlea, and scala vestibuli. He described the tympanic cavity, "Cavum tympani" $(5,6)$.

Along with these huge contributions to anatomy, he also had numerous contributions to clinical practice. He was the first to distinguish between the syphilitic condyloma lata and condylama acuminata. Despite knowing the importance of mercury in the treatment of syphilis, he used guaiac tree in the treatment as well because of the side effects of mercury. He was the first to mention that a condom is useful against syphilis; he produced simple condoms made out of linen, tried them on 1100 men, and reported that syphilis was not transmitted to any of them. He developed a new method for nasal polyp treatment. He described tubal pregnancy, known as ectopic pregnancy (4).

Many researchers from the cities all over Europe came to visit Falloppio and made use of his knowledge and methods. Some experts claim that Falloppio's contributions to anatomy are greater than those of Vesalius. Unfortunately, he died in 1562 at the age of 39 (5). This leading figure of Padua Medical School is immortalized in medical history, especially with his works on anatomy. Let us discuss, parenthetically, the Padua Medical School, which has an important place in medical history.

Founded in 1222, Padua University is one of the first universities in the world. Initially, it mostly provided law education. In the 1250 's, it began offering medical education as well. The long-term adventure of anatomy and surgery be- 
gan with Bruno da Longobucco (1200-1286). Even though not much is known about his life, it is known that he received his education in Salerno Medical School, worked in Bologna, wrote a book called "Chirurgia Magna" (Great Surgery), arrived in Padua in the mid-thirteenth century, and was one of the best physicians in that century. Detailed information about the early years of the Padua Medical School is not available. It is well known that the books of Hippocrates and Galen and translations of the works of Muslim physicians (Avicenna, al-Razi) were read, and that these works were critiqued and improved upon. The chair of anatomy-surgery only became a distinct chair at the end of the $14^{\text {th }}$ century. Consequently, documentation picked up pace starting from those dates.

The modern anatomy age began with the arrival of Vesalius of Brussels in Padua in 1537, and many anatomical discoveries were made. Vesalius, who performed public dissections, garnered a big audience. After the departure of Vesalius, great anatomists such as Realdo Colombo (15161559), Gabriele Falloppio (1523-1562), and Hieronymus Fabricius ab Aquapendente (1533-1619) also worked in Padua and gave anatomy its golden age. Fabricius had the first permanent amphitheater-shaped dissection room built called the anatomy theater, in 1594. This room made a huge difference in anatomy education as it enabled 300 people to simultaneously observe dissections performed (11-14). This room is preserved as a museum at Padua University (Figure 3).

Many physicians and students from various cities in Europe came to Padua to learn anatomy and conduct research. Some of these were the following: the Founder of Royal College of Physicians, Thomas Linacre (1460-1524); Werner Rolfinck (1599-1673) who built anatomy theaters in Germany

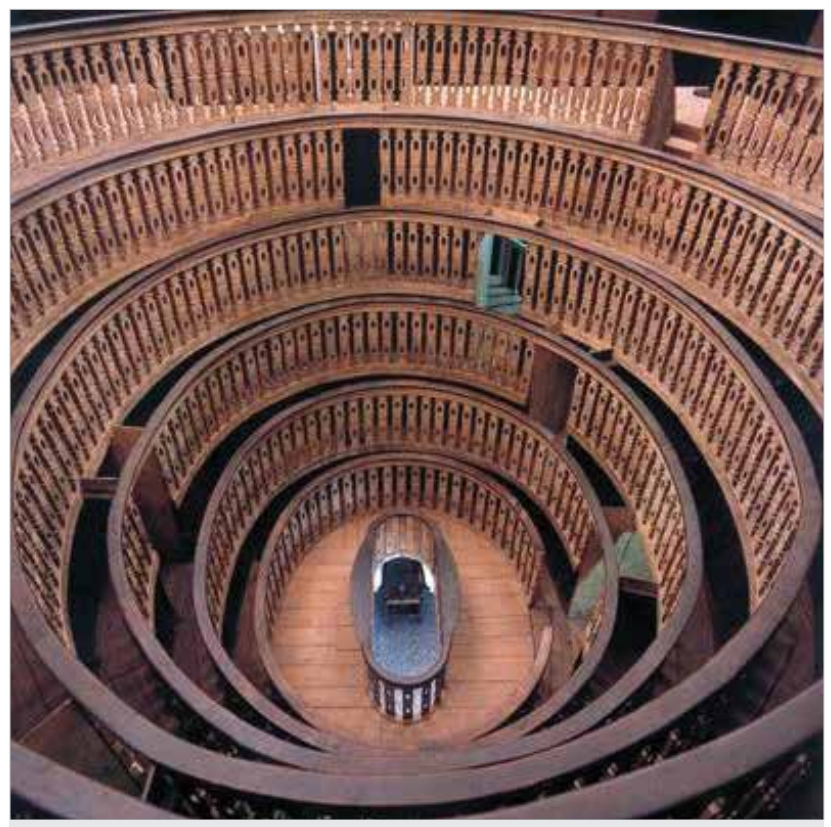

Resim 3. Padua Üniversitesi'ndeki tarihi diseksiyon salonu "Anatomi Tiyatrosu" and Sweden based on the Padua model; and Olof Rudbeck (1630-1702). In the $17^{\text {th }}$ century, anatomical understanding expanded toward embryology, developmental anatomy, and investigating the functions of organs, and seminal works that transformed the history and understanding of medicine were produced in these areas. Exercitatio Anatomica by William Harvey (1578-1657) and De Sedibus by Giovanni Battista Morgagni (1682-1771), who is considered to be the founder of pathological anatomy, examine the clinical findings and postmortem autopsy findings of patients. Padua Medical School continues this old tradition to date and hosts many national and international meetings and congresses $(11,14,15)$.

The most important reason for anatomy and medicine becoming so advanced in Padua University compared with other universities in Europe was its free environment. In particular, in the $16^{\text {th }}$ and $17^{\text {th }}$ centuries, dissections were performed in a very restricted way in other universities, particularly because of religious reasons. Padua University was the exact opposite. The university achieved this freedom by being a part of the independent and rich Republic of Venice. Throughout its history, the university endorsed the following motto: Universa universis patavina libertas, meaning "Paduan freedom is universal for everyone" (15-17).

Peer-review: Externally peer-reviewed.

Conflict of Interest: No conflict of interest was declared by the authors.

Financial Disclosure: The authors declared that this study has received nofinancial support.

\section{References}

1. Wells WA. Gabriel Fallopio, one of the 16th century founders of modern anatomy; also distinguished physician and surgeon, 1523-1562. Laryngoscope 1948; 58: 33-42. [CrossRef]

2. Kothary PC, Kothary SP. Gabriele Fallopio. Int Surg 1975; 60: 80-1.

3. Joutsivuo T. Vesalius and De humani corporis fabrica: Galen's errors and the change of anatomy in the sixteenth century. Hippokrates 1997: 98-112.

4. Mortazavi MM, Adeeb N, Latif B, Watanabe K, Deep A, Griessenauer CJ, et al. Gabriele Fallopio (1523-1562) and his contributions to the development of medicine and anatomy. Childs Nervous System 2013; 29: 877-80. [CrossRef]

5. Ellis H. Gabriele Falloppio (Fallopius): a father of modern anatomy. British Journal Hospital Medicine 2012; 73: 709. [CrossRef]

6. Macchi V, Porzionato A, Morra A, De Caro R. Gabriel Falloppius (1523-1562) and the facial canal. Clinical Anatomy 2014; 27: 4-9. [CrossRef]

7. McHenry LC. Garrison's History of Neurology. İllinois: Charles C Thomas; 1969 .

8. Persaud TVN. A History of Human Anatomy. 2nd ed. Illinois: Charles C Thomas; 2014.

9. Speert H. Gabriele Fallopio and the fallopian tubes. Obstetric Gynecology 1955;6:467-70.

10. Thiery M. Gabriele Fallopio (1523-1562) and the Fallopian tube. Gynecological Surgery 2009; 93-5. [CrossRef]

11. Simeone FA. Andreas Vesalius: anatomist, surgeon, count palatine, and pilgrim. American Journal of Surgery 1984; 147: 432-40. [CrossRef] 
12. Smith SB, Macchi V, Parenti A, De Caro R. Hieronymus Fabricius Ab Aquapendente (1533-1619). Clinical Anatomy 2004; 17: 540-3. [CrossRef]

13. Finger S. Minds behind brain. New York: Oxford University Press; 2000.

14. Porzionato A, Macchi V, Stecco C, Parenti A, De Caro R. The anatomical school of Padua. Anatomical Record 2012; 295: 902-16. [CrossRef]
15. Andrioli G, Trincia G. Padua: the renaissance of human anatomy and medicine. Neurosurgery 2004; 55: 746-54. [CrossRef]

16. Garrison FH. History of Medicine 4th ed. Philadelphia: W.B. Saunders Company; 1966.

17. Ongaro G. 2001a. Scientific and Cultural History: the Medieval and Early Modern University-Medicine. In: Del Negro P, editor. The University of Padua: eight centuries of history. Padova: Signum Ed; 2001.p.112-20. 